\title{
Spectroscopic Investigations of Iron(II) and Iron(III) Oxalates
}

\author{
Maria C. D'Antonio, ${ }^{a, b}$ Alejandra Wladimirsky, ${ }^{a}$ Daniel Palacios, ${ }^{a}$ Liliana Coggiola, ${ }^{a}$ \\ Ana C. González-Baró, ${ }^{c}$ Enrique J. Baran ${ }^{*, c}$ and Roberto C. Mercader ${ }^{d}$ \\ ${ }^{a}$ Departamento de Ciencias Básicas, UTN-Unidad Académica Río Gallegos, 9400 Río Gallegos, Argentina \\ ${ }^{b}$ Departamento de Ciencias Exactas y Naturales, Universidad Nacional de la Patagonia Austral, \\ 9400 Río Gallegos, Argentina \\ ${ }^{c}$ Centro de Química Inorgánica and ${ }^{d}$ Departamento de Física and Instituto IFLP (CONICET), \\ Facultad de Ciencias Exactas, Universidad Nacional de La Plata, 1900 La Plata, Argentina
}

\begin{abstract}
Na tentativa de contribuir para uma melhor caracterização dos complexos de $\mathrm{Fe}^{\mathrm{II}}$ e $\mathrm{Fe}^{\mathrm{III}}$ com o ânion oxalato, uma investigação dos seus espectros vibracionais (infravermelho e Raman) e espectros Mössbauer de ${ }^{57} \mathrm{Fe}$ foi realizada. Foi observado que os dois polimorfos de $\mathrm{FeC}_{2} \mathrm{O}_{4} \cdot 2 \mathrm{H}_{2} \mathrm{O}$, $\alpha$ and $\beta$, não podem ser diferenciados com exatidão por nenhum destes métodos espectroscópicos, demonstrando uma alta similaridade estrutural das duas formas cristalinas. Amostras parcialmente deuteradas de $\beta-\mathrm{FeC}_{2} \mathrm{O}_{4} \cdot 2 \mathrm{H}_{2} \mathrm{O}$ também foram investigadas para aprimorar a análise espectroscópica vibracional. No caso do $\mathrm{Fe}_{2}\left(\mathrm{C}_{2} \mathrm{O}_{4}\right)_{3} \cdot 4 \mathrm{H}_{2} \mathrm{O}$, um modelo estrutural pôde ser proposto a partir dos resultados dos dados vibracionais e de Mössbauer combinados. O espectro de Mössbauer registrado a $298 \mathrm{~K}$ para este complexo é discutido em detalhes pela primeira vez.
\end{abstract}

In an attempt to contribute to a better characterization of $\mathrm{Fe}^{\mathrm{II}}$ and $\mathrm{Fe}^{\mathrm{III}}$ oxalate complexes, an investigation of their vibrational (infrared and Raman) and ${ }^{57} \mathrm{Fe}$-Mössbauer spectra was performed. It is shown that the two polymorphs, $\alpha$ and $\beta$, of $\mathrm{FeC}_{2} \mathrm{O}_{4} \cdot 2 \mathrm{H}_{2} \mathrm{O}$ cannot be accurately differentiated with any of these spectroscopic methods, demonstrating the high structural similarity of these two crystalline forms. Partially deuterated samples of $\beta-\mathrm{FeC}_{2} \mathrm{O}_{4} \cdot 2 \mathrm{H}_{2} \mathrm{O}$ were also investigated to improve the vibrational-spectroscopic analysis. In the case of $\mathrm{Fe}_{2}\left(\mathrm{C}_{2} \mathrm{O}_{4}\right)_{3} \cdot 4 \mathrm{H}_{2} \mathrm{O}$, a structural model, derived from results of combined vibrational and Mössbauer data, could be proposed. The $298 \mathrm{~K}$ Mössbauer spectrum for this complex is discussed in detail for the first time.

Keywords: iron oxalates, IR spectroscopy, Raman spectroscopy, Mössbauer

\section{Introduction}

Metal cation oxalate deposits formed during biodeterioration processes of minerals by the action of lichens or fungi have been reported in the scientific literature. ${ }^{1-3}$ It is also well known that calcium oxalates are frequently produced as normal or pathological biominerals by different forms of life, ${ }^{3-5}$ and their wide distribution in the plant kingdom is well documented. ${ }^{3,4,6}$ On the other hand, metal oxalates have been used as chemical precursors of synthetic nanomaterials, ceramic superconductors or catalysts. ${ }^{3,7}$

As part of our studies about oxalate biominerals ${ }^{3}$ and biomineralization processes in plants,,${ }^{6,8,9}$ we have initiated different studies to attain a wider insight into the general

\footnotetext{
*e-mail: baran@quimica.unlp.edu.ar
}

physicochemical properties of metal oxalates. ${ }^{10}$ In this paper we report results of an investigation based on the spectroscopic behavior of iron(II) and iron(III) oxalates.

The naturally formed dihydrated $\mathrm{Fe}^{\mathrm{II}}$ oxalate, $\mathrm{FeC}_{2} \mathrm{O}_{4} \cdot 2 \mathrm{H}_{2} \mathrm{O}$, is the mineral humboldtine. ${ }^{3,11}$ Interestingly, evidences of this oxalate have so far never been found at mineral/lichen interfaces. One may speculate that possibly a microbial oxidation of $\mathrm{Fe}^{\mathrm{II}}$ to $\mathrm{Fe}^{\mathrm{III}}$ occurs, followed by hydrolysis and precipitation of different degrees of crystalline $\mathrm{Fe}^{\mathrm{III}}$ oxides. ${ }^{1,3}$ The occurrence of an iron(III) oxalate has been reported for the lichen Calopia callopsima growing on an iron-rich dolomite, ${ }^{12}$ although the formation of this oxalate has later been questioned. ${ }^{2}$

On the other hand, it is well established that dihydrated oxalates of different divalent transition metal cations, including iron, are dimorphic, adopting either the $\alpha-\mathrm{M}^{\mathrm{II}} \mathrm{C}_{2} \mathrm{O}_{4} \cdot 2 \mathrm{H}_{2} \mathrm{O}$ form $\left(\mathrm{M}^{\mathrm{II}}=\mathrm{Mg}^{2+}, \mathrm{Fe}^{2+}, \mathrm{Co}^{2+}, \mathrm{Ni}^{2+}, \mathrm{Zn}^{2+}\right)$, 
for which the prototype is humboldtine, or its derived $\beta-\mathrm{M}^{\mathrm{II}} \mathrm{C}_{2} \mathrm{O}_{4} \cdot 2 \mathrm{H}_{2} \mathrm{O}$ form. ${ }^{3,13}$ Besides, the corresponding $\mathrm{Fe}^{\mathrm{III}}$ compound is so far not so well characterized, and information on its structural features is not available.

\section{Experimental}

\section{Syntheses}

The $\mathrm{Fe}^{\mathrm{II}}$ oxalates were obtained by slow mixing of diluted solutions of ferrous ammonium sulfate and oxalic acid. Working with a slight excess of the acid renders preferentially $\alpha-\mathrm{Fe}\left(\mathrm{C}_{2} \mathrm{O}_{4}\right) \cdot 2 \mathrm{H}_{2} \mathrm{O}$, whereas the $\beta-\mathrm{Fe}\left(\mathrm{C}_{2} \mathrm{O}_{4}\right) \cdot 2 \mathrm{H}_{2} \mathrm{O}$ is generated by limiting the acid concentration. ${ }^{14}$ Both microcrystalline precipitates were characterized by their typical X-ray powder diffractograms,${ }^{14}$ using a Philips PW 1710 diffractometer and $\mathrm{Cu}-\mathrm{K}_{\alpha}$ radiation $(\lambda=1.5425 \AA)$.

For the synthesis of partially deuterated $\beta-\mathrm{Fe}\left(\mathrm{C}_{2} \mathrm{O}_{4}\right) \cdot 2 \mathrm{H}_{2} \mathrm{O}$ samples, the same procedure as above was employed, but working directly with $3 \mathrm{~mL}$ of $\mathrm{D}_{2} \mathrm{O}$ at a micro-scale level.

$\mathrm{Fe}^{\mathrm{III}}$ oxalate from Aldrich and used as supplied. The chemical analysis for this product confirmed a $\mathrm{Fe}_{2}\left(\mathrm{C}_{2} \mathrm{O}_{4}\right)_{3} \cdot 4 \mathrm{H}_{2} \mathrm{O}$ stoichiometry $(\mathrm{C}=16.15 ; \mathrm{H}=1.83 ; \mathrm{Fe}=$ 24.68 mass\%; calculated values for $\mathrm{C}_{6} \mathrm{H}_{8} \mathrm{Fe}_{2} \mathrm{O}_{16}: \mathrm{C}=16.08$; $\mathrm{H}=1.79 ; \mathrm{Fe}=24.95$ mass $\%$ ).

\section{Spectroscopic measurements}

The infrared spectra in the range of $4000-400 \mathrm{~cm}^{-1}$ were recorded with an FTIR Bruker EQUINOX-55 instrument, using the $\mathrm{KBr}$ pellet technique. Raman spectra, in the same spectral range, were measured on powdered samples using the FRA 106 Raman accessory of an IF66 Bruker spectrophotometer. Radiation from a Nd:YAG solid-state laser $(1064 \mathrm{~nm})$ was used for excitation.

Room temperature ${ }^{57} \mathrm{Fe}$ Mössbauer spectra were taken in transmission geometry using a conventional constant acceleration spectrometer of 512 channels with a $10 \mathrm{mCi}$ nominal activity ${ }^{57} \mathrm{Co} / \mathrm{Rh}$ source. The hyperfine parameters were obtained by fitting the data to Lorentzian shape lines using a least-squares computer code with constraints. Isomer shifts were calibrated against an $\alpha$-Fe foil at room temperature.

\section{Results and Discussion}

\section{$F e^{I I}$ oxalates}

\section{Crystal structure of the complexes}

Oxalate complexes of $\mathrm{M}^{\mathrm{II}}\left(\mathrm{C}_{2} \mathrm{O}_{4}\right) \cdot 2 \mathrm{H}_{2} \mathrm{O}$ stoichiometry, with $\mathrm{M}^{\mathrm{II}}=\mathrm{Mg}^{2+}, \mathrm{Fe}^{2+}, \mathrm{Co}^{2+}, \mathrm{Ni}^{2+}$ and $\mathrm{Zn}^{2+}$, display two crystalline modifications. ${ }^{3,13}$ The prototype of the most stable form, usually referred to as $\alpha-\mathrm{M}^{\mathrm{II}}\left(\mathrm{C}_{2} \mathrm{O}_{4}\right) \cdot 2 \mathrm{H}_{2} \mathrm{O}$, is the mineral humboldtine $\left(\alpha-\mathrm{Fe}\left(\mathrm{C}_{2} \mathrm{O}_{4}\right) \cdot 2 \mathrm{H}_{2} \mathrm{O}\right)$. It belongs to the monoclinic space group $C 2 / c$ with $\mathrm{Z}=4$. The metal cations and oxalate groups generate an infinite chain arrangement as depicted in Figure 1, where the oxalate acts as a tetradentate (bridging) ligand. Each $\mathrm{M}^{\mathrm{II}}$ cation is additionally coordinated to two water molecules, generating a distorted octahedral $\mathrm{MO}_{6}$ environment. These chains generate ordered sheets lying perpendicularly to the $c$ axis of the unit cell. ${ }^{13,14}$

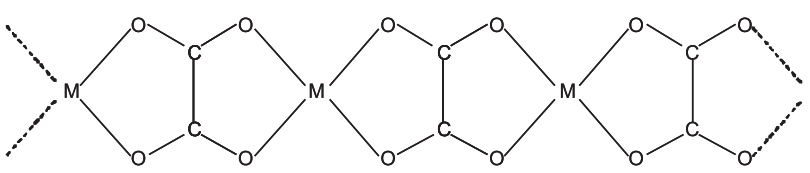

Figure 1. Schematic drawing of the infinite chain arrangement present in $\mathrm{M}^{\mathrm{II}}$ oxalates of composition $\mathrm{M}^{\mathrm{II}}\left(\mathrm{C}_{2} \mathrm{O}_{4}\right) \cdot 2 \mathrm{H}_{2} \mathrm{O}$.

The second crystal modification, $\beta-\mathrm{M}^{\mathrm{II}}\left(\mathrm{C}_{2} \mathrm{O}_{4}\right) \cdot 2 \mathrm{H}_{2} \mathrm{O}$, is very similar, showing only a certain degree of disorder in the piling of successive sheets, which causes a reordering of the hydrogen bonds between sheets. This second form usually is irreversibly transformed to the most stable modification by heating, or by prolonged contact with the mother liquor during the synthesis, and crystallizes in the orthorhombic $\mathrm{Cccm}$ space group with $\mathrm{Z}=8 .{ }^{14}$

As mentioned above, our $\mathrm{X}$-ray powder diffractograms confirmed the monoclinic structure for $\alpha-\mathrm{Fe}\left(\mathrm{C}_{2} \mathrm{O}_{4}\right) \cdot 2 \mathrm{H}_{2} \mathrm{O}$ and the orthorhombic one for $\beta-\mathrm{Fe}\left(\mathrm{C}_{2} \mathrm{O}_{4}\right) \cdot 2 \mathrm{H}_{2} \mathrm{O}$.

\section{Vibrational spectra}

The IR and Raman spectra for both crystalline polymorphs of $\mathrm{Fe}\left(\mathrm{C}_{2} \mathrm{O}_{4}\right) \cdot 2 \mathrm{H}_{2} \mathrm{O}$ are practically identical, confirming the strong molecular structure similarities between them. To illustrate the general spectral pattern for both samples, those of $\alpha-\mathrm{Fe}\left(\mathrm{C}_{2} \mathrm{O}_{4}\right) \cdot 2 \mathrm{H}_{2} \mathrm{O}$, in the spectral range between 2000 and $400 \mathrm{~cm}^{-1}$, are shown in Figure 2.

Spectral investigations of complexes in which oxalate acts as a tetradentate ligand showed that the corresponding patterns are relatively simple in the high frequency region, ${ }^{15}$ a situation which is confirmed in the present case.

The now proposed assignments are based on the spectroscopic behavior of the "free" oxalate anion, ${ }^{16}$ in comparisons with well-known data from spectroscopic studies of a great variety of metal oxalates resumed by Nakamoto, ${ }^{17}$ as well as on the results of our recent study of synthetic moolooite, $\mathrm{Cu}\left(\mathrm{C}_{2} \mathrm{O}_{4}\right) \cdot 0.2 \mathrm{H}_{2} \mathrm{O},{ }^{10}$ in which the metal cation displays, in the plane, an identical chain structure as that depicted in Figure 1. The proposed assignments are shown in Table 1. 
Table 1. Assignment of the vibrational spectra of the two modifications of $\mathrm{Fe}\left(\mathrm{C}_{2} \mathrm{O}_{4}\right) \cdot 2 \mathrm{H}_{2} \mathrm{O}$ (band positions in $\mathrm{cm}^{-1}$ )

\begin{tabular}{|c|c|c|c|c|}
\hline \multicolumn{2}{|c|}{$\alpha-\mathrm{Fe}\left(\mathrm{C}_{2} \mathrm{O}_{4}\right) \cdot 2 \mathrm{H}_{2} \mathrm{O}$} & \multicolumn{2}{|c|}{$\beta-\mathrm{Fe}\left(\mathrm{C}_{2} \mathrm{O}_{4}\right) \cdot 2 \mathrm{H}_{2} \mathrm{O}$} & \multirow[t]{2}{*}{ Assignment } \\
\hline IR & Raman & IR & Raman & \\
\hline 3343 vs, br & & $3342 \mathrm{vs,br}$ & & $v(\mathrm{OH})\left(\mathrm{H}_{2} \mathrm{O}\right)$ \\
\hline \multirow[t]{2}{*}{1625 vs } & & $1625 \mathrm{vs}$ & & $v(\mathrm{C}-\mathrm{O})$ \\
\hline & 1489vs, 1450sh & & 1490vs, 1450sh & $v(\mathrm{C}-\mathrm{O})$ \\
\hline $1361 \mathrm{~s}$ & & $1361 \mathrm{~s}$ & & $v(\mathrm{C}-\mathrm{O})$ \\
\hline \multirow[t]{2}{*}{1317 vs } & & 1317 vs & & $v(\mathrm{C}-\mathrm{O})$ \\
\hline & $913 \mathrm{~s}$ & & $907 \mathrm{~s}$ & $v(\mathrm{C}-\mathrm{C})$ \\
\hline $822 \mathrm{~s}$ & & $820 \mathrm{~s}$ & & $\delta(\mathrm{O}-\mathrm{C}-\mathrm{O})+v(\mathrm{C}-\mathrm{C})$ \\
\hline $765 / 718 w$ & & $755 / 714 \mathrm{w}$ & & $\rho\left(\mathrm{H}_{2} \mathrm{O}\right)$ \\
\hline $531 \mathrm{~m}$ & $580 / 520 \mathrm{~m}$ & $540 \mathrm{~m}$ & $590 / 528 \mathrm{~m}$ & $\delta_{\text {ring }}$ \\
\hline $493 \mathrm{~s}$ & & $493 \mathrm{~s}$ & & $v(\mathrm{Fe}-\mathrm{O})(?)$ \\
\hline
\end{tabular}

Band intensities: vs, very strong; s, strong; m, medium; w, weak; br, broad; sh, shoulder.

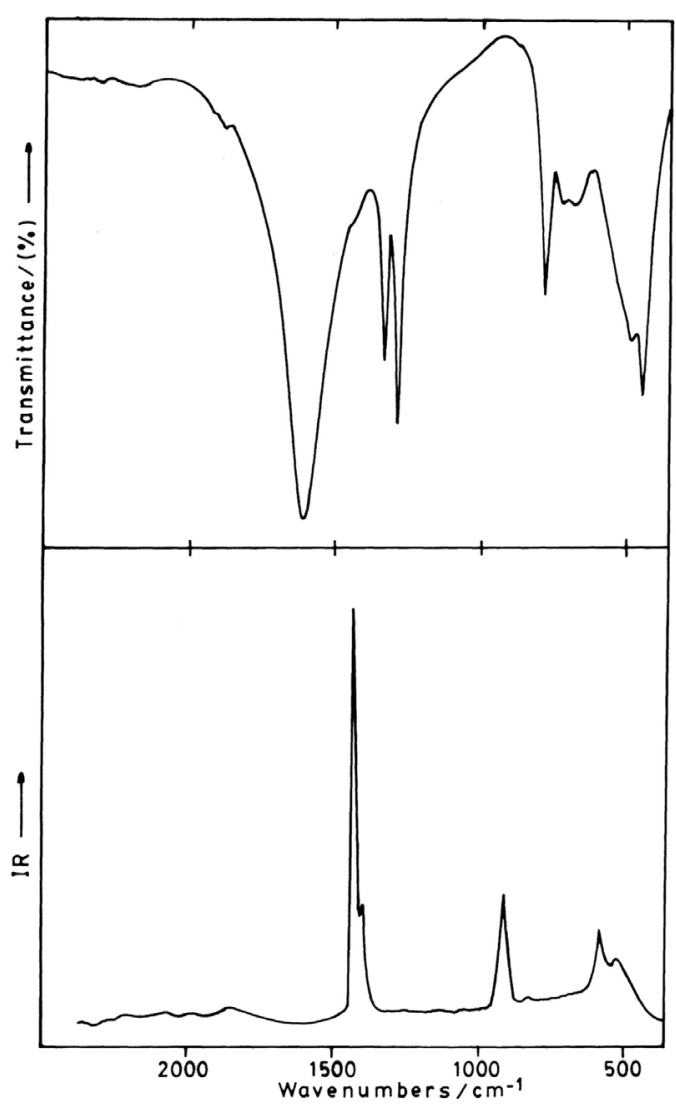

Figure 2. FT-Infrared (above) and Raman spectra (below) of $\alpha-\mathrm{Fe}\left(\mathrm{C}_{2} \mathrm{O}_{4}\right) \cdot 2 \mathrm{H}_{2} \mathrm{O}$ in the spectral range between 2000 and $400 \mathrm{~cm}^{-1}$.

The comparison of the IR spectra in the highest frequency region, related to the water stretching motions, does not show significant differences between the two crystalline forms. Both complexes present a very strong and broad band centered at about $3340 \mathrm{~cm}^{-1}$, totally similar in their general shape and structure. The bending mode,
$\delta\left(\mathrm{H}_{2} \mathrm{O}\right)$, certainly overlaps with the strong and broad IR band centered at $1625 \mathrm{~cm}^{-1}$. Only in the lower frequency region small energy differences could be observed, although the form of the bands is identical.

In order to attain a better insight into the possible origin of these low energy bands we have performed deuteration experiments and measured the IR spectra of partially deuterated samples of $\beta-\mathrm{Fe}\left(\mathrm{C}_{2} \mathrm{O}_{4}\right) \cdot 2 \mathrm{H}_{2} \mathrm{O}$, analyzing the observed band shifts using the Teller-Redlich product rule. ${ }^{18}$ This analysis is presented in Table 2 and briefly commented as follows: (i) According to the Teller-Redlich product rule, in deuteration experiments the expected $v_{\mathrm{H}} / \nu_{\mathrm{D}}$ ratio must be close to 1.41 , although due to coupling and anharmonicity effects this ratio is usually found to lie between 1.2 and 1.4. ${ }^{18}$ (ii) After deuteration of a $\beta-\mathrm{Fe}\left(\mathrm{C}_{2} \mathrm{O}_{4}\right) \cdot 2 \mathrm{H}_{2} \mathrm{O}$ sample, the $v(\mathrm{O}-\mathrm{H})$ stretching band of the water molecules generates a new, very strong band centered at $2512 \mathrm{~cm}^{-1}$ with a weak shoulder at $2458 \mathrm{~cm}^{-1}$, both of which fulfill the above requirement. (iii) The deformational mode of water appears as a medium intensity band at $1184 \mathrm{~cm}^{-1}$, confirming the assumption that $\delta\left(\mathrm{H}_{2} \mathrm{O}\right)$ is overlapped by the intense

Table 2. Analysis of the band shifts of $\beta-\mathrm{Fe}\left(\mathrm{C}_{2} \mathrm{O}_{4}\right) \cdot 2 \mathrm{H}_{2} \mathrm{O}$ after partial deuteration (band positions in $\mathrm{cm}^{-1}$ )

\begin{tabular}{lcc}
\hline Normal sample/Table 1 & Part. deuterated sample & $\mathrm{v}_{\mathrm{H}} / \mathrm{v}_{\mathrm{D}}$ \\
\hline $3342 \mathrm{vs}, \mathrm{br}$ & $2512 \mathrm{vs} / 2458 \mathrm{sh}$ & $1.33 / 1.26$ \\
ca. 1620 (overlapped) & $1184 \mathrm{~m}$ & 1.37 \\
$820 \mathrm{~s}$ & $809 \mathrm{~s}$ & 1.01 \\
$755 / 714 \mathrm{w}$ & $450 \mathrm{~m}$ & 1.58 \\
$540 \mathrm{~m}$ & $545 \mathrm{~m}$ & \\
$493 \mathrm{~s}$ & $495 \mathrm{~s}$ & \\
\hline
\end{tabular}

Band intensities: vs, very strong; s, strong; m, medium; w, weak; br, broad; sh, shoulder. 
$1625 \mathrm{~cm}^{-1}$ oxalate band. (iv) The weak $755 / 714 \mathrm{~cm}^{-1}$ doublet disappears after deuteration, indicating clearly that it must be related to the proposed vibrational modes of coordinated water. This assignment is reinforced by the fact that no bands in this region are found in the case of $\mathrm{Cu}\left(\mathrm{C}_{2} \mathrm{O}_{4}\right) \cdot n \mathrm{H}_{2} \mathrm{O}$ samples, in which water is not coordinated to copper(II), but is of "zeolitic" nature. ${ }^{10}$ Besides, the fact that the shift of this doublet generates a new band at $450 \mathrm{~cm}^{-1}$, with a relatively high $v_{\mathrm{H}} / v_{\mathrm{D}}$ ratio, suggests that this last band probably involves an additional vibrational mode. ( $v)$ The small shift of the $820 \mathrm{~cm}^{-1}$ band, which does not fulfill the Teller-Redlich rule, suggests that its origin may be eventually more complex than suggested in Table 1. (vi) The constancy of the position of the last two bands after deuteration clearly shows that they are not involved in water motions. We have tentatively assigned them to a Fe-O stretching vibration.

Finally, it is interesting to mention that our IR and Raman spectra are similar to those previously reported by Edwards and Russell for a structurally uncharacterized $\mathrm{Fe}\left(\mathrm{C}_{2} \mathrm{O}_{4}\right) \cdot 2 \mathrm{H}_{2} \mathrm{O}$ sample. Their spectroscopic analysis was performed without any structural consideration. ${ }^{19}$

\section{Mössbauer spectra}

As it was not possible to differentiate the two forms of iron(II) oxalate by means of their IR and Raman spectra, we have tried to verify if this would be possible through their Mössbauer spectra. However, as indicated by the two spectra in Figure 3, and hyperfine parameter values in Table 3, the interactions at the $\mathrm{Fe}^{\mathrm{II}}$ sites of the two forms are identical within the experimental uncertainties, and hence make it also impossible to establish any difference by means of this technique. The small asymmetry observed in the $\mathrm{L}_{1} / \mathrm{L}_{2}$ ratio may be due to a slight texture or preferential orientation of the sample. The values of $\mathrm{L}_{1} / \mathrm{L}_{2}$ obtained after the fittings are $1.06 \pm 0.01$ for the $\alpha$-polymorph and $1.07 \pm 0.01$ for the $\beta$-polymorph.

Isomer shifts, $\delta$, lie clearly in the range expected for $\mathrm{Fe}^{\mathrm{II}}$ in octahedral or quasi-octahedral environments, usually found between 1.06 and $1.29 \mathrm{~mm} \mathrm{~s}^{-1} .^{20,21}$ On the other hand, the quadrupole splitting $(\Delta \mathrm{Q})$ values are consistent with the high spin electronic configuration for the $\mathrm{Fe}^{\mathrm{II}}$ cation. ${ }^{22}$ These results compare very well with earlier measurements performed on $\alpha-\mathrm{Fe}\left(\mathrm{C}_{2} \mathrm{O}_{4}\right) \cdot 2 \mathrm{H}_{2} \mathrm{O} .{ }^{23}$

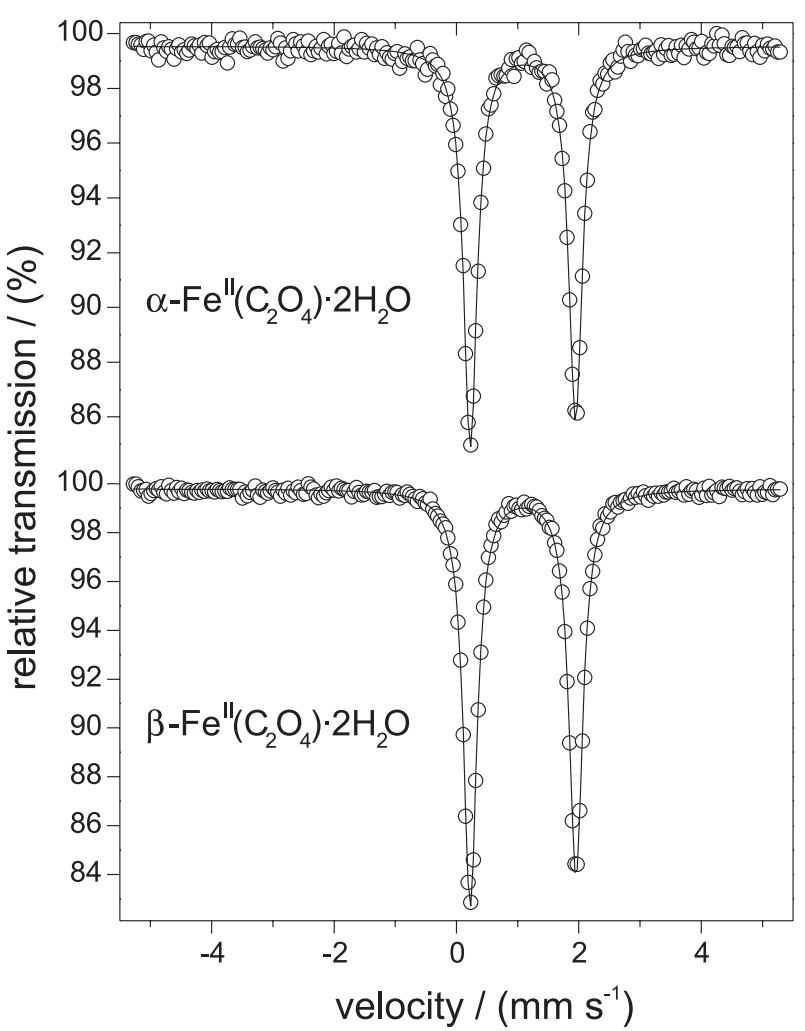

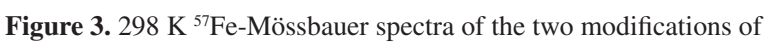
$\mathrm{Fe}\left(\mathrm{C}_{2} \mathrm{O}_{4}\right) \cdot 2 \mathrm{H}_{2} \mathrm{O}$.

$F e^{I I I}$ oxalate

\section{Vibrational spectra}

The structure of ferric oxalate has so far not been determined. Therefore, it is interesting to advance in its structural characterization using spectroscopic information. The FTIR spectrum of one of the investigated samples is shown in Figure 4. Unfortunately, no good quality Raman spectra could be obtained for this compound. The spectra have usually a very poor signal to noise ratio and only a very limited number of bands could be unambiguously identified. Both the IR and the Raman spectra show strong similarities with those previously reported for a hexahydrated ferric oxalate sample. ${ }^{19}$

A comparison of the IR spectrum of ferric oxalate with those of the previously commented ferrous complexes immediately indicates important differences, pointing to different structural arrangements. The presence of a high

Table 3. Hyperfine parameters derived from the Mössbauer spectra of the two polymorphic forms of $\mathrm{Fe}\left(\mathrm{C}_{2} \mathrm{O}_{4}\right) \cdot 2 \mathrm{H}_{2} \mathrm{O}$ and of Fe $\left(\mathrm{C}_{2} \mathrm{O}_{4}\right) \cdot 4 \mathrm{H}_{2} \mathrm{O}$ at $298 \mathrm{~K}_{2}$. The isomer shifts $\delta$ are referred to $\alpha-\mathrm{Fe}$ at $298 \mathrm{~K}$

\begin{tabular}{lccr}
\hline Complex & $\delta /\left(\mathrm{mm} \mathrm{s}^{-1}\right)$ & $\Delta \mathrm{Q} /\left(\mathrm{mm} \mathrm{s}^{-1}\right)$ & $\Gamma /\left(\mathrm{mm} \mathrm{s}^{-1}\right)$ \\
\hline$\alpha-\mathrm{Fe}\left(\mathrm{C}_{2} \mathrm{O}_{4}\right) \cdot 2 \mathrm{H}_{2} \mathrm{O}$ & $1.19(1)$ & $1.72(1)$ & $0.27(1)$ \\
$\beta-\mathrm{Fe}\left(\mathrm{C}_{2} \mathrm{O}_{4}\right) \cdot 2 \mathrm{H}_{2} \mathrm{O}$ & $1.20(1)$ & $1.73(1)$ & $0.27(1)$ \\
$\mathrm{Fe}_{2}\left(\mathrm{C}_{2} \mathrm{O}_{4}\right)_{3} \cdot 4 \mathrm{H}_{2} \mathrm{O}$ & $0.38(1)$ & $0.39(1)$ & $0.28(1)$ \\
\hline
\end{tabular}




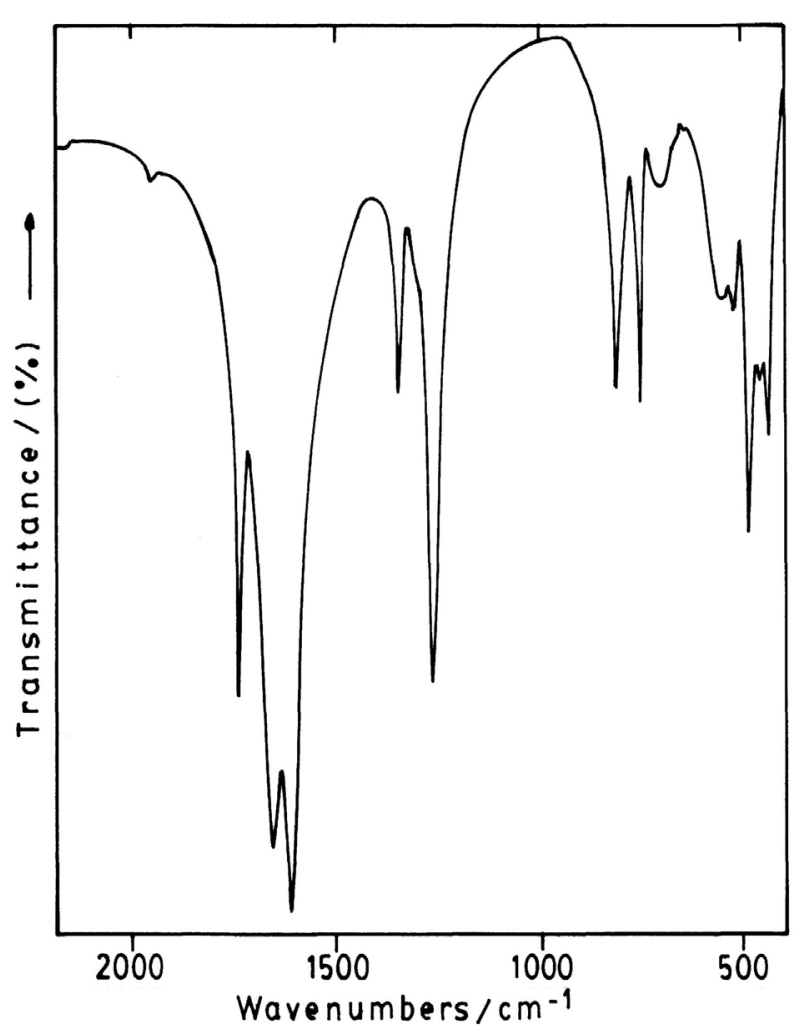

Figure 4. FT-Infrared spectrum of $\mathrm{Fe}_{2}\left(\mathrm{C}_{2} \mathrm{O}_{4}\right)_{3} \cdot 4 \mathrm{H}_{2} \mathrm{O}$ in the spectral range between 2000 and $400 \mathrm{~cm}^{-1}$.

energy IR band $\left(1736 \mathrm{~cm}^{-1}\right)$, with no Raman counterpart, immediately suggests the presence of terminal carbonyl groups. Besides, a comparison of the IR spectrum with those of ionic oxalates ${ }^{16}$ excludes the possibility of an ionic structure and, on the other hand, for stoichiometric reasons the formation of a dimeric complex must be expected. As the corresponding Mössbauer spectrum (see next section) confirms the equivalence of these dimeric sites and the octahedral coordination, one plausible structural arrangement may be similar to that shown in Figure 1, but containing only one pair of metal centers, disrupting the polymeric structure. This implies the presence of a central oxalate group acting as a tetradentate ligand bridging the two $\mathrm{Fe}^{\mathrm{III}}$ cations, and two terminal (bidentate) oxalate ligands, each interacting with only one of the metal centers. The coordination of the cations is completed by two water molecules, lying again perpendicularly to the iron/oxalate linkage.

The proposed spectral assignment for this complex is shown in Table 4. Stretching vibrations of the water molecules are clearly identified in the IR spectrum, and lie somewhat higher than in the ferrous oxalates, whereas the corresponding bending mode, $\delta\left(\mathrm{H}_{2} \mathrm{O}\right)$, is surely overlapped by the strong $1655 / 1612 \mathrm{~cm}^{-1}$ IR doublet. A pair of IR and Raman bands can unambiguously be assigned to the antisymmetric and symmetric stretchings of the terminal carboxylate groups, respectively. Two groups of $v(\mathrm{C}-\mathrm{C})$
Table 4. Assignment of the vibrational spectra of $\mathrm{Fe}_{2}\left(\mathrm{C}_{2} \mathrm{O}_{4}\right)_{3} \cdot 4 \mathrm{H}_{2} \mathrm{O}$ (band positions in $\mathrm{cm}^{-1}$ )

\begin{tabular}{ccc}
\hline Infrared & Raman & Assignment \\
\hline $3350 \mathrm{~m}, 3501 \mathrm{w}$ & & $v(\mathrm{O}-\mathrm{H})\left(\mathrm{H}_{2} \mathrm{O}\right)$ \\
$1736 \mathrm{~s}$ & & $v_{\text {as }}(\mathrm{C}-\mathrm{O})_{\text {term }}$ \\
& $1623 \mathrm{~m}$ & $v_{\mathrm{s}}(\mathrm{C}-\mathrm{O})_{\text {term }}$ \\
$1655 \mathrm{vs}, 1612 \mathrm{vs}$ & & $v(\mathrm{C}-\mathrm{O})$ \\
& $1493 \mathrm{vs}, 1467 \mathrm{~m}$ & $v(\mathrm{C}-\mathrm{O})$ \\
$1349 \mathrm{~m}, 1295 \mathrm{sh}$, & $1254 \mathrm{w}$ & $v(\mathrm{C}-\mathrm{O})+v(\mathrm{C}-\mathrm{C})$ \\
$1265 \mathrm{~s}$ & & $v(\mathrm{C}-\mathrm{C})+\delta(\mathrm{O}-\mathrm{C}-\mathrm{O})$ \\
$816 \mathrm{~m}, 759 \mathrm{~m}$ & & $\mathrm{see}$ text \\
$705 \mathrm{w}$ & & $\rho\left(\mathrm{H}_{2} \mathrm{O}\right)$ \\
& & \\
$557 \mathrm{~m}, 528 \mathrm{~m}$ & $556 \mathrm{~s}$ & $\rho\left(\mathrm{H}_{2} \mathrm{O}\right)+\mathrm{v}(\mathrm{Fe}-\mathrm{O})(?)$ \\
$462 \mathrm{w}, 439 \mathrm{~m}$ & $465 \mathrm{w}$ & \\
\hline
\end{tabular}

Band intensities: vs, very strong; s, strong; m, medium; w, weak.

motions have been assigned in agreement with the presence of two structurally different oxalate groups in the structure; one of them overlaps with the $v(\mathrm{C}-\mathrm{O})$ stretchings and the other with an oxalate deformational mode. The weak $705 \mathrm{~cm}^{-1}$ IR band is probably of a similar complex nature as the $755 / 714 \mathrm{~cm}^{-1}$ doublet analyzed in the case of $\beta-\mathrm{Fe}\left(\mathrm{C}_{2} \mathrm{O}_{4}\right) \cdot 2 \mathrm{H}_{2} \mathrm{O}$. In the lower frequency region, water librational modes have been tentatively assigned and also a reasonable value for one of the $\mathrm{Fe}-\mathrm{O}$ stretching vibrations ${ }^{17}$ is proposed.

\section{Mössbauer spectrum}

There is no reported ${ }^{57} \mathrm{Fe}$ Mössbauer data available for ferric oxalate, except for brief mentions made in two papers, one investigating the thermal behavior of oxalatoferrate(III) complexes ${ }^{24}$ and other from a study of mixed ligand oxalate complexes of $\mathrm{Fe}^{\mathrm{III}} .{ }^{25}$

The spectrum of $\mathrm{Fe}_{2}\left(\mathrm{C}_{2} \mathrm{O}_{4}\right)_{3} \cdot 4 \mathrm{H}_{2} \mathrm{O}$ is shown in Figure 5 and the derived hyperfine parameters are included in Table 3. The presence of a unique quadrupole doublet of

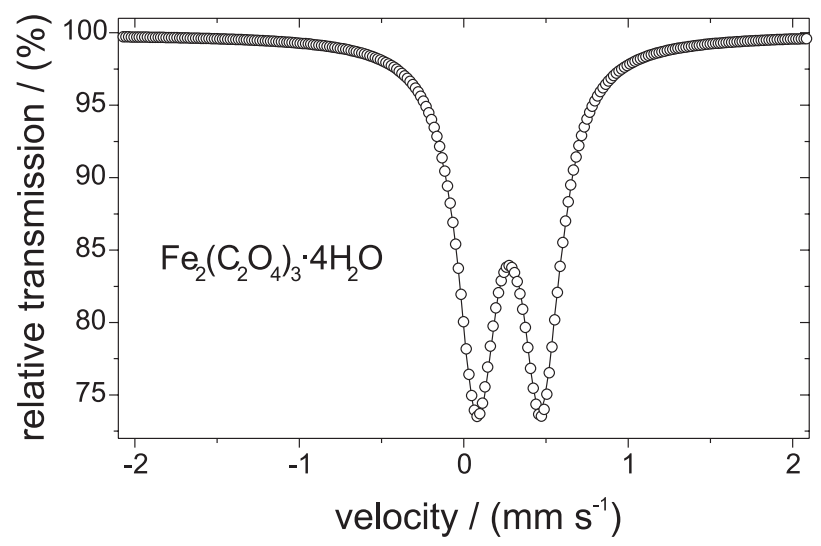

Figure 5. $298 \mathrm{~K}{ }^{57} \mathrm{Fe}-$ Mössbauer spectrum of $\mathrm{Fe}_{2}\left(\mathrm{C}_{2} \mathrm{O}_{4}\right)_{3} \cdot 4 \mathrm{H}_{2} \mathrm{O}$. 
narrow line width, $\Gamma$, clearly confirms that both $\mathrm{Fe}^{\mathrm{III}}$ cations present the same environment. The observed isomer shift lies clearly in the range expected for an octahedral $\mathrm{Fe}^{\mathrm{III}} \mathrm{O}_{6}$ environment. ${ }^{20,21}$ Besides, the relatively low quadrupole splitting, which is appreciably lower than those found in mixed ligand $\mathrm{Fe}^{\mathrm{III}}$ oxalato complexes, ${ }^{25}$ indicates the presence of a scarcely distorted octahedral environment and a high spin electronic configuration for $\mathrm{Fe}^{\mathrm{III}}$.

\section{Conclusions}

It is demonstrated that the two polymorphic forms of $\mathrm{Fe}\left(\mathrm{C}_{2} \mathrm{O}_{4}\right) \cdot 2 \mathrm{H}_{2} \mathrm{O}$ cannot be differentiated by means of their vibrational (IR and Raman) and ${ }^{57} \mathrm{Fe}$ Mössbauer spectra, confirming the close structural relationship between these two forms. Some of the performed vibrational spectroscopic assignments could be supported by measurements with partially deuterated samples.

On the other hand, and also combining vibrational and Mössbauer data, it was possible to make, for the first time, a structural proposal for the corresponding $\mathrm{Fe}^{\mathrm{III}}$ oxalate of composition $\mathrm{Fe}_{2}\left(\mathrm{C}_{2} \mathrm{O}_{4}\right)_{3} \cdot 4 \mathrm{H}_{2} \mathrm{O}$. The structures of the oxalates of both oxidation states of iron are closely related. In the ferrous complex, $\mathrm{Fe}^{\mathrm{II}}$ and oxalate groups generate an infinite chain arrangement, with the anion acting as a tetradentate ligand and each cation additionally coordinated to two water molecules, originating a distorted $\mathrm{Fe}^{\mathrm{II}} \mathrm{O}_{6}$ octahedral environment. In the case of the ferric complex, the polymeric structure is disrupted, presenting only a central tetradentate oxalate group bridging the two $\mathrm{Fe}^{\mathrm{III}}$ cations and two terminal bidentate ligands, each interacting with only one metal ion, which also in this case completes its coordination sphere with two water molecules, generating again a $\mathrm{Fe}^{\mathrm{III}} \mathrm{O}_{6}$ environment.

\section{Acknowledgments}

This work has been supported by the Consejo Nacional de Investigaciones Científicas y Técnicas de la República Argentina-CONICET, the Universidad Tecnológica Nacional and the Universidad Nacional de La Plata. A.C.G-B., E.J.B. and R.C.M. are members of the Research Career from CONICET.

\section{References}

1. Adamo, P.; Violante, P.; Appl. Clay Sci. 2000, 16, 229.
2. Chen, J.; Blume, H. P.; Beyer, L.; Catena 2000, 39, 121.

3. Baran, E. J.; Monje, P.V. In Metal Ions in Life Sciences; Sigel, A.; Sigel, H.; Sigel, R. K. O., eds.; J. Wiley: Chichester, 2008, vol. 4 , ch. 7.

4. Khan, S. R., ed.; Calcium Oxalate in Biological Systems, CRCPress: Boca Raton, 1995.

5. Baran, E. J.; Química Bioinorgánica, McGraw-Hill Interamericana de España: Madrid, 1995.

6. Monje, P. V.; Baran, E. J. In Advances in Plant Physiology; Hemantaranjan, A., ed.; Scientific Publishers: Jodhpur, 2004, vol. 7 , ch. 15 .

7. Donkova, B.; Mehandjev, D.; J. Mater. Sci. 2005, 40, 3881.

8. Monje, P. V.; Baran, E. J.; Plant Physiol. 2002, 128, 707.

9. Monje, P. V.; Baran, E. J.; Phytochemistry 2005, 66, 611.

10. D’Antonio, M. C.; Palacios, D.; Coggiola, L.; Baran, E. J.; Spectrochim. Acta 2007, 68A, 424.

11. Strunz, H.; Mineralogische Tabellen, $7^{\text {th }}$ ed., Geest \& Portig: Leipzig, 1978.

12. Ascaso, C.; Galvan, J.; Rodríguez-Pascual, C.; Pedobiologia 1982, 24, 219.

13. Lagier, J. P.; Pezerat, H.; Dubernat, J.; Rev. Chim. Miner. 1969, 6, 1081.

14. Deyrieux, R.; Peneloux, A.; Bull. Soc. Chim. Fr. 1969, 2675.

15. Scott, K. L.; Wieghardt, K.; Sykes, G.; Inorg. Chem. 1973, 12, 655.

16. Begun, K. M.; Fletcher, W. H.; Spectrochim. Acta 1963, 19, 1343.

17. Nakamoto, K.; Infrared and Raman Spectra of Inorganic and Coordination Compounds, $5^{\text {th }}$ ed., J. Wiley: New York, 1997.

18. Siebert, H.; Anwendungen der Schwingungsspektroskopie in der Anorganischen Chemie, Springer: Berlin, 1966.

19. Edwards, H. G. M.; Russell, N. C.; J. Mol. Struct. 1998, 443, 223.

20. Menil, F.; J. Phys. Chem. Solids 1985, 46, 763.

21. Mercader, R. C.; Baran, E. J.; Weil, M.; J. Phys. Chem. Solids 2006, 67, 1781.

22. Drago, R. S.; Physical Methods in Inorganic Chemistry, Reinhold Publ.: New York, 1965.

23. Wrobleski, J. T.; Brown, D. B.; Inorg. Chem. 1979, 18, 2738, and references therein.

24. Gallagher, P. K.; Kurkjian, C. R.; Inorg. Chem. 1966, 5, 214.

25. Abras, A.; Figueiredo de Oliveira, E.; Hyperfine Interact. 1991, 66, 271.
Received: March 27, 2008

Web Release Date: February 13, 2009 